\title{
Social Desirability Bias in self-reported well- being Measures: Evidence from an online survey
}

\section{Sesgo de deseabilidad social en las medidas de bienestar por autoinforme: evidencia de una encuesta en línea}

Received: 24 February 2015 | Accepted: 25 January 2017

\author{
Andrea Caputo ${ }^{a}$ \\ University "Sapienza" of Rome, Italia \\ ORCID: http://orcid.org/0000-0003-3516-8332
}

a Autora de correspondencia. Correo electrónico: andrea.caputo@uniromal.it

How to cite: Caputo, A. (2017). Social desirability bias in self-reported well-being measures: evidence from an online survey. Universitas Psychologica, 16(2), 1-13. https://doi.org/10.11144/Javeriana.upsy16-2.sdsw

\begin{abstract}
Social desirability seems to enhance well-being measures because individuals tend to increase the degree of their satisfaction and happiness resulting in response artifacts and in a serious threat to the validity of self-reported data. This paper explores social desirability bias in self-reported subjective well-being, controlling for several sociodemographic variables such as gender, age, education, marital/relationship status, and employment status. This is in order to test whether social desirability has incremental validity in predicting some well-being measures. Three different facets of well-being are proposed which deal with subjective happiness, general life satisfaction, and gratitude and loneliness, respectively regarded as a positive and negative emotional response. Through a web-based survey a convenience sample of 170 participants completed an online questionnaire including measures of social desirability, subjective happiness, life satisfaction, gratitude, and loneliness. Correlation analyses and two-step hierarchical multiple regression analyses were conducted. All well-being measures show modest significant correlations with social desirability ranging from 0.235 to 0.309 , except subjective happiness. Social desirability accounted for from about $3 \%$ to $6 \%$ of the variance of these measures, after controlling for socio-demographic variables. Social desirability seems thus to play little role in well-being self-report measures, as revealed by previous studies. Some limitations are discussed, as well as issues about social desirability bias in online investigation.

Keywords

social desirability bias; psychological well-being; web-based survey; happiness; gratitude

\section{RESUMEN}

La deseabilidad social parece mejorar las medidas de bienestar, pues los individuos tienden a aumentar el grado de satisfacción y felicidad que resulta en artefactos de respuesta y en una seria amenaza para la validez de los datos por autoinforme. Este artículo explora el sesgo de deseabilidad social en el bienestar subjetivo autodeclarado, controlando variables sociodemográficas, como el género, la edad, la educación, el estado civil/ familiar y la situación laboral, con el fin de probar si la deseabilidad social tiene un incremento en la validez para predecir algunas medidas de
\end{abstract}


bienestar. Se proponen tres facetas del bienestar que tratan de la felicidad subjetiva: 1 . la satisfacción general con la vida, 2. la gratitud y 3. la soledad, respectivamente, consideradas como una respuesta emocional positiva y negativa. A través de una encuesta en línea, una muestra de conveniencia de 170 participantes completó un cuestionario en línea que incluía medidas de deseabilidad social, felicidad subjetiva, satisfacción con la vida, gratitud y soledad. Se realizaron análisis de correlación y análisis de regresión jerárquica de dos etapas. Todas las medidas de bienestar muestran modestas correlaciones significativas con deseabilidad social que van desde 0.235 a 0.309 , excepto la felicidad subjetiva. La deseabilidad social representó entre 3 y $6 \%$ de la varianza de estas medidas, después de controlar las variables sociodemográficas. Por tanto, la deseabilidad social parece desempeñar un papel pequeño en las medidas de autorreporte de bienestar, como lo revelaron estudios previos. Se discuten algunas limitaciones y cuestiones sobre el sesgo de deseabilidad social en la investigación en en línea.

Palabras clave

sesgo de deseabilidad social; bienestar psicológico; encuesta en línea; felicidad; gratitud

Validity and interpretation of self-reports of subjective well-being represent two relevant research issues which have led to a critical debate (Brajsa-Zganec, Ivanovic, \& Lipovcan, 2011). As stated by Kozma and Stones (1988), an important consideration for anyone employing self-report questionnaires or scales is the extent to which such measures are free from response bias, even more so in health psychology. Indeed, measures of subjective well-being can be influenced by current situational factors, individual's mood and, particularly, by social desirability response bias (Diener, 2000). In more detail, social desirability refers to the individual's tendency to respond in a more socially desirable manner in certain situations (Richman, Weisband, Kiesler, \& Drasgow, 1999) and reflects what one believes will lead to approval from others or avoiding their disapproval (Crowne \& Marlowe, 1960). It is typically characterized by the tendency of respondents using self-report questionnaires to answer in such a way as to make themselves look good, to give positive self-descriptions, often at the expense of honesty and/or accuracy (Holtgraves, 2004; Paulhus, 2002). In this regard, the strong discrepancy between the typical findings of positive psychology and observations of human behavior in several environments seem to confirm that socially desirable responding may undermine the validity of measures of positive subjective well-being (Holder, 2012). It is common for societies to emphasize that their members act in an agreeable and pleasant manner, even when an individual is experiencing a negative mood or an adverse situation (Eysenck, 1990). In this sense, social desirability seems to enhance wellbeing (McCrae, 2002), because individuals tend to increase the degree of their satisfaction and happiness through their self-reports resulting in response artifacts (Penezić \& Ivanov, 1999). Socially desirable responding can account for anywhere from $10 \%$ to $75 \%$ of the overall variance of individuals' responses (Nederhof, 1985) and thus it is a serious threat to the validity of self-reported data (Tan \& Grace, 2008). Indeed, important information is lost when social desirability is removed from life satisfaction measures (Diener, Sandvik, Pavot, \& Gallagher, 1991; Forgeard, Jayawickreme, Kern, \& Seligman, 2011). However, most researchers of subjective well-being do not include measures of social desirability (Gallagher \& Vella-Brodrick, 2008) and it is thus impossible to evaluate the same shared source of variance existing between social desirability and subjective wellbeing (McCrae, 1986).

\section{Theoretical Framework and Aim of the Study}

Subjective well-being can be defined as optimal psychological functioning that refers to three basic characteristics (Diener, 1984): it is subjective and depends on experience; it includes not only absence of negative affects but positive affects as well; and it refers to subjective evaluation of all aspects of an individual's life. According to Ryan and Deci (2001), it is conceptualized as relying on perceived happiness, judgments of good and bad elements of life, and pleasant versus unpleasant experiences. In order to make realistic evaluations of subjective well- 
being, it is thus necessary to use both cognitive and affective measures (Kaliterna-Lipovčan \& Prizmić-Larsen, 2006). At the cognitive level, subjective well-being refers to life satisfaction, regarded as the cognitive evaluation of life as a whole (Pavot, Diener, Colvin, \& Sandrik, 1991); while at the affective level it includes the presence of positive emotions, as well as the absence of the negative ones (Diener, 1984). However, as stated by Eysenck (1990), many societies place an emphasis on behaving in an agreeable and pleasant manner, regardless of a person's current mood or circumstances. The current definition of well-being, thus, fosters a strong cultural expectation that unhappiness is not acceptable and should be hidden, and unhappy people may attempt to imitate the behaviors of those who are genuinely happy, in order to fit in. Research on other positive socially desirable behaviors and attitudes, such as the over-reporting of ethical behavior at work (Randall \& Fernandes, 1991) and church attendance (Presser \& Stinson, 1998), as well as the over-reporting of the rejection of patriarchal beliefs (Burris \& Jackson, 1999), suggests that self-reports of happiness and subjective wellbeing may also be over-reported. These discrepancies raise the possibility that people may be responding to measures of happiness in a socially desirable manner. In this regard, it is demonstrated that both life satisfaction (Steel \& Ones, 2002) and well-being-related emotional responses may be biased by social desirability (Brajsa-Zganec et al., 2011; Fastame \& Penna, 2013), defined as the tendency of individuals to regulate their answers to establish a positive impression, avoid criticism, or satisfy a need for social approval (Crowne \& Marlowe, 1960). For example, Chen, Dai, Spector, and Jex (1997) found that items designed to assess positive affect were much more likely to be endorsed by people who score high on a measure of social desirability. Furthermore, personality traits judged more desirable are also much more likely to be endorsed by people who score high on measures of social desirability (Bäckström, Björklund, \& Larsson, 2009; DeYoung, Peterson,
\& Higgins, 2002; Konstabel, Aavik, \& Allik, 2006; Kuncel \& Tellegen, 2009).

This paper aims at exploring the relationship between social desirability and subjective wellbeing, controlling for several socio-demographic variables which could affect this relationship (Brajša-Žganec \& Kaliterna-Lipovčan, 2006; Diener \& Biswas-Diener, 2002; Diener, Suh, \& Oishi, 1997; Kaliterna-Lipovčan \& PrizmićLarsen, 2006; Pavot \& Diener, 2004), such as gender, age, education, marital/relationship status, and employment status. This is in order to test whether social desirability has incremental validity in predicting some wellbeing measures. Indeed, there are known sociodemographic differences in rates of subjective well-being, which is higher in males (Piccinelli \& Wilkinson, 2000; Sigmon et al., 2005) and tends to decline with age and to increase with higher standards of education (Watson, Pichler, \& Wallace, 2010). Then, married people are consistently shown to be happier than those who are divorced, widowed, or single (Myers, 2000); while unemployed people generally have permanent and significant decreases in life satisfaction levels (Lucas, Clark, Georgellis, \& Diener, 2004).

Consistently with this theoretical framework, our study proposes three different facets of wellbeing which deal with subjective happiness, general life satisfaction, and gratitude and loneliness, respectively regarded as a positive and negative emotional response. Indeed, gratitude is demonstrated to be a positive affect that is strongly related to well-being and life satisfaction (Caputo, 2015; Wood, Froh, \& Geraghty, 2010); on the other hand research suggests that loneliness contributes negatively to well-being (Ben-Zur, 2012; Feng, 2011).

We decided not to use general measures on positive and negative affects (such as anger, joy, fear, etc.) because the existing scales do not succeed in thoroughly sampling the emotions involved in well-being experience and do not consent to adequately differentiate the desirability of different feelings (Diener, 2009). Therefore, we preferred to focus on two complex emotions (i.e. gratitude and loneliness) 
whose interpersonal nature better grasps the feeling of connectedness as central component of subjective wellbeing in terms of efficient interaction with the world and social integration (Karademas, 2007).

\section{Method}

Participants and Procedure

A Web-based survey was promoted via social media to study the relationship between subjective well-being and other related psychological constructs. It was conducted according to online survey design, development, and implementation guidelines suggested by Andrews, Nonnecke and Preece (2003). Online survey was chosen because of its widespread use for quality of life, health-related, and wellbeing research (Vereecken \& Maes, 2006) and its easy access to geographically diverse respondent groups across the national context (Evans \& Mathur, 2005). In addition, the validity and reliability of Internet research for subjective well-being surveys were demonstrated to be comparable to those of the paper-based versions (Howell, Rodzon, Kurai, \& Sanchez, 2010).

For the recruitment process two Italian forums were detected. They are popular and nationally widespread online sites where people communicate around several common sets of interests, without specific regard to quality of life, health-related, and well-being issues. This was in order to reduce the potential self-selection bias of individuals who share information and discuss for specific purposes related to the topic of our research study. An invitation to participate in a survey about psychological wellbeing was posted in the forums and respondents clicking a link were directed to a questionnaire. A convenience sample of 170 participants was recruited (138 women and 38 men) whose mean age was 29.98 $(S D=10.39)$. A questionnaire was administered which included socio-demographic information and social desirability, subjective happiness, life satisfaction, gratitude, and loneliness measures. Participants were guaranteed anonymity. For the present study $100 \%$ of the respondents filled in the complete questionnaire without missing data.

\section{Measures}

Subjective happiness.

The Subjective Happiness Scale (SHS) (Lyubomirsky \& Lepper, 1999) is a widely used four-item scale, measuring global subjective happiness. The scale required participants to use absolute ratings to characterize themselves as happy or unhappy individuals on a 7 point Likert scale; it asked as well as to what extent they identify themselves with the description of happy and unhappy individuals. The score was calculated as the mean of items, ranging from 1 to 7 . Higher scores mean greater perceived happiness. The Italian version of the scale was used (Duncan \& Grazzani-Gavazzi, 2004) and showed a Cronbach's alpha of 85 .

Life satisfaction. As a measure of global life satisfaction, a three-item scale was specifically developed and used for the purpose of the study. Subjects had to rate how much they were satisfied with three dimensions respectively regarding socio-economic status, general health status, and life style and conditions, using a 10-point scale where 1 meant 'totally disagree' and 10 meant 'totally agree'. The score was calculated as the sum of items, ranging from 3 to 30 . Higher scores mean better life satisfaction. The scale showed good psychometric properties, with a one-factor solution explaining $68.1 \%$ of the total variance and a Cronbach's alpha of .72.

Gratitude. The Gratitude Questionnaire-SixItem Form (GQ-6) (McCullough, Emmons, $\&$ Tsang, 2001) is a six-item self-report questionnaire designed to assess individual differences in the proneness to experience expressions of gratefulness and appreciation in daily life, as well as feelings about receiving from others. Respondents endorsed each item on a 7-point Likert-type scale (where $1=$ strongly disagree and $7=$ strongly agree). The score was calculated as the sum of items, ranging from 6 to 42 . Higher scores mean higher proneness to 
experience gratitude in daily life. For the purpose of this study, the scale was adapted to the Italian language through translation, back translation and equivalence evaluation, and showed a onefactor solution explaining $46.2 \%$ of the total variance and a satisfactory internal consistency $(\alpha=.74)$.

Loneliness. The Three-Item Loneliness Scale, developed by Hughes, Waite, Hawkley and Cacioppo (2004) from the revised UCLA Loneliness Scale (Russell, Peplau, \& Cutrona, 1980), was used to assess loneliness consisting of feelings of isolation, disconnectedness, and not belonging. The response categories were coded 1 (hardly ever), 2 (some of the time), and 3 (often) on a 3-point scale. Each person's responses to the questions are summed, with higher scores indicating greater loneliness. For the purpose of this study, the three items were derived from the Italian version of the revised UCLA Loneliness Scale (Solano \& Coda, 1994). The 3-item scale showed a one-factor solution explaining 78\% of the total variance and a very good internal consistency $(\alpha=0.86)$.

Social desirability. The Italian adaptation (Manganelli Rattazzi, Canova, \& Marcorin, 2000) of the short 9\#item version of the Marlowe\#Crowne Social Desirability Scale (MCSDS) (Crowne and Marlowe, 1960) was used to measure social desirability. Participants were requested to respond to each item on a $7 \#$ point scale ranging from $1=$ Absolutely false to $7=$ Absolutely true. A total score is derived from the sum of all items, ranging from 7 to 63 . Higher scores indicate higher levels of social desirability. Internal consistency was sufficient $(\alpha=.61)$. The relatively low Cronbach's alpha seems to be in agreement with other studies using the Italian short version of the MC-SDS (Maino \& Aceti, 1997; Manganelli Rattazzi et al., 2000).

\section{Statistical Procedures}

To explore the relationship between social desirability and each well-being measure considered (subjective happiness, life satisfaction, gratitude, and loneliness), correlation analyses were performed. Given the sample size equal to 170 , power to detect a hypothesized effect size of .02 (from small to medium effect) for two-tailed correlations at the .05 level was .84 .

Then, in order to test whether social desirability bias could explain unique variance in well-being dimensions after controlling for the effects of socio-demographic characteristics, four two-step hierarchical multiple regression analyses were conducted. Socio-demographic characteristics were entered in the first step and social desirability in the second one so as to see the amount of variance explained independently by socio-demographic characteristics and together with social desirability, and thus to assess whether social desirability had incremental validity. Power to detect a hypothesized incremental effect size of .05 (a small effect) at the .05 level in the final step of this regression was .83. With regard to socio-demographic predictors, a dummy for gender (male, female) and three dummies respectively for marital/ relationship status (married/cohabitant, in a relationship, single) and employment status (employed, unemployed, others) were created. On the other hand, age and education were inserted as continuous variables. Power analyses were performed using the Gpower computer program and all other analyses using SPSS 16.0.

\section{Results}

In Table 1 socio-demographic variables of our sample are reported, as well as descriptive characteristics of subjective well-being measures. 


\section{TABLE 1}

Socio-demographic variables and descriptive characteristics of subjective well-being measures of the sample $(\mathrm{N}=170)$

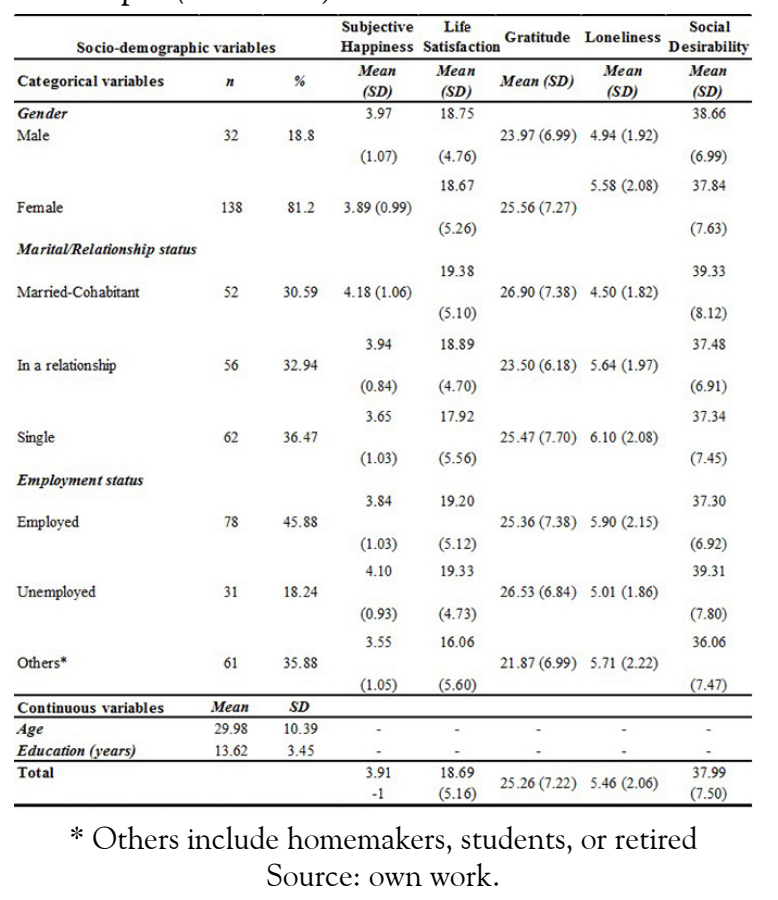

As shown in Table 2, higher level of social desirability was found to be related to higher levels of life satisfaction and gratitude, and a lower level of loneliness. Despite these correlations being statistically significant, their effect size is quite modest (ranging from .235 to .309). Instead, no correlation between social desirability and subjective happiness was detected.

\section{TABLE 2}

Correlations between social desirability and subjective well-being measures

\begin{tabular}{lc}
\hline Subjective Well-being measure & Social Desirability \\
Subjective Happiness & 0.135 \\
Life Satisfaction & $0.235^{* *}$ \\
Gratitude & $0.309^{* *}$ \\
Loneliness & $-0.252^{* *}$ \\
\hline
\end{tabular}

** Correlation is significant at the 0.01 level Source. own work.
The results of hierarchical multiple regression analyses (Table 3) indicated that sociodemographic variables together accounted for $9.7 \%$ of the variance of subjective happiness, $10.1 \%$ of life satisfaction, $12.8 \%$ of gratitude, and $16.9 \%$ of loneliness.

\section{TABLE 3}

Summary of hierarchical multiple regression analyses of socio-demographic characteristics and social desirability for subjective well-being measures

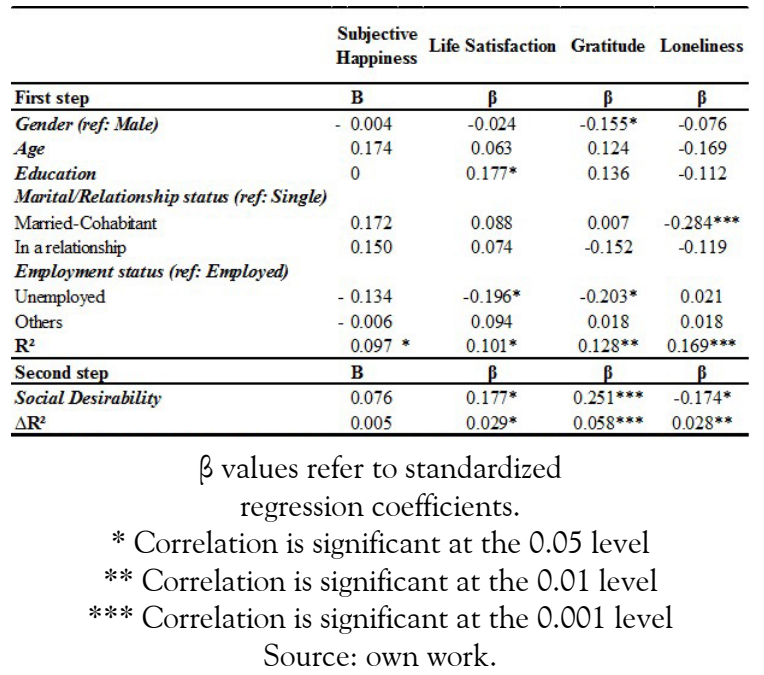

In more detail, males showed lower gratitude than females, greater education was associated to higher life satisfaction, married/ cohabitant subjects had lower level of loneliness, and unemployed subjects reported lower life satisfaction and gratitude. These results show that, although socio-demographic factors are associated to measures of subjective well-being, their effect is not constant. Moreover, they do not seem to account for a significant amount of variance of well-being measures.

The inclusion of social desirability into analyses increased prediction for additional almost $3 \%$ of variance on life satisfaction and loneliness and $6 \%$ on gratitude, whereas no association was detected between social desirability and subjective happiness. 


\section{Discussion}

Our study reveals a quite modest relationship between social desirability and measures of wellbeing, consistent with findings from Diener's (1984) review of the literature. The highest correlation is with gratitude, probably recognized by the respondents as a pro-social and altruistic disposition that is culturally agreeable, as suggested by previous research (Bono, Emmons, \& McCullough, 2004; Emmons \& Crumpler, 2000; Lyubomirsky, Sheldon, \& Schkade, 2005; Watkins, 2004; Wood et al., 2010; Wood, Joseph, \& Linley, 2007). On the contrary, social desirability is negatively correlated with loneliness, consistent with our theoretical framework, because of the selfdeceptive tendency to hide undesirable feelings related to low emotional well-being (Lasgaard, Goossens, \& Elklit, 2011). However, this association could be also due to the influence of social desirability regarded as a personality trait, because people with low social desirability are generally less affiliative and thus more vulnerable to loneliness (Powling \& Hopes, 1988).

Then, our study confirms the lack of correlation between social desirability and subjective happiness, as emerged in other studies (Veenhoven, 1991) which did not find any problem of social desirability bias in literature reviews on happiness measures. In this regard, Konow and Earley (2008) presented experimental evidence which showed that overall happiness measures were not significantly correlated with the score of the MarloweCrowne scale (Crowne \& Marlowe, 1960), probably because they could be less affected by social approval bias compared to other positive emotions such as gratitude.

With regard to the results of hierarchical multiple regression analyses, socio-demographic variables show that being female, not married/ cohabitant, less educated, and unemployed tend to lower subjective well-being, as demonstrated in previous studies (Lucas et al., 2004; Myers, 2000; Piccinelli \& Wilkinson, 2000; Sigmon et al., 2005; Watson et al., 2010). Instead, age does not seem to play any role. However, these factors do not explain the variance of well-being measures as successfully as expected (Inglehart, 2002; Inglehart \& Klingemann, 2000).

Overall, the contamination of social desirability bias invalidating research results can be considered as minimal (from 3\% to $6 \%$ of explained variance), in line with previous works on the topic (Diener, Emmons, Larsen, \& Griffin, 1985; Kozma \& Stones, 1988). In this regard, a study by Konow and Earley (2008) found that 11 of 14 well-being measures correlated significantly with social desirability, although social desirability accounted for no more than $10 \%$ of the variance in any of the well-being measures.

\section{Conclusions}

The aim of this study was to explore the relationship between social desirability and subjective well-being measures, controlling for several socio-demographic variables, as well as to test whether social desirability had incremental validity in predicting these well-being measures.

Overall, results suggest a significant positive association between social desirability and life satisfaction and gratitude, whereas there is a negative correlation with loneliness. However, a negligible and non-systematic social desirability effect (Diener, 1984) was detected. The correlations were modest and social desirability accounted for from about 3\% to $6 \%$ of the variance of these measures, after controlling for socio-demographic variables. Social desirability seems thus to play little, if any role, in well-being self-report measures, as revealed by previous studies (Kozma \& Stones, 1988).

However, there is controversy regarding whether social desirability scales assess a response style or bias that may distort self-reports, or whether they assess a personality trait which actually enhances well-being (McCrae \& Costa, 1983; Smith \& Ellingson, 2002). Indeed, there is considerable evidence that social desirability is correlated with stable disposition such as the Big Five dimensions (Li \& Bagger, 2006), higher selfesteem, ego-resiliency, and conscientiousness 
(Paulhus, 2002), lower levels of depression, social anxiety, neuroticism, and empathic distress (Holden, Starzyk, Mcleod, \& Edwards, 2000). Therefore, correlations between measures of well-being and social desirability could be more readily attributed to content similarity between these constructs than to a social desirability response bias in well-being measures (Kozma \& Stones, 1988). As stated by Soubelet and Salthouse (2011):

To the extent that social desirability scales measure a stable disposition to behave in a particular manner, and not merely to produce favorable self report responses, partialling variance associated with social desirability scales may be removing meaningful variance from the relevant trait, and may not increase the validity of personality measures or subjective well-being measures (p. 742).

Personality assessment could thus be helpful to determine how much of the variance in subjective well-being measures is accounted for by social desirability over and above the variance accounted for by personality (Costa \& McCrae, 1984; DeNeve \& Cooper, 1998; Li \& Bagger, 2006). In this regard, social desirability measures should not include some types of items which refer to both, stable traits or psychopathological conditions (e.g. "I sometimes feel that I am about to go to pieces") and overlapping constructs such as life satisfaction or happiness (e.g. "I am happy most of the time") ${ }^{\mathrm{i}}$. Indeed, on the one hand, it may not be clear whether answers are really affected by social desirability or by the lack of symptoms and psychological distress; on the other hand, problems of multicollinearity and variance inflation could emerge in statistical analyses.

Another recommendation could be to use social desirability measures including both impression management and self-deception dimensions in order to further disentangle the relationship between social desirability and subjective well-being facets. We can hypothesize that well-being self-reports in online surveys may be mostly affected by self-deception, as unintentional propensity to portray oneself in a favorable light, rather than by intentional falsification (mostly assessed by traditional social desirability measures, such as the Marlowe-
Crowne Scale). In more detail, we should focus on the agentic or egoistic bias which involves exaggerating one's social or well-being status, whereas the moralistic or communal bias involves denying socially deviant impulses and claiming pious attributes.

In addition, some forms of control and demand reduction (Paulhus, 1991) could be employed with specific regard to online investigation. They may include methods which mitigate the situational demands for desirable responding, such as guaranteeing the anonymity of the respondents or using a set of instructions which provide respondents with tacit permission to report honest levels of subjective well-being (for instance, by indicating that non-optimal well-being reports in the general population are quite common, and therefore, acceptable).

Some limitations regarding this study need to be taken into account in order to put the findings into perspective. The study used a sample of convenience which was not a national representation and was not randomly chosen. Issues regarding self-selection bias may thus exist which do not allow generalization. However, according to the Gosling, Vazire, Srivastava, and John (2004) study, this bias would be equally present with any form of recruitment beyond that of random sampling. Then, the nature of this research does not enable conclusions on causal relations between examined variables, because correlation analyses and self-report measures also have inherent limitations. Another limitation refers to the relatively low internal consistency of the social desirability measure used (the short version of the MCSDS), as also revealed by previous Italian studies (Maino \& Aceti, 1997; Manganelli Rattazzi et al., 2000). Results have thus to be interpreted cautiously and need further investigation. However, this may also depend on the scarce adequateness of commonly used social desirability scales in web-based surveys. Indeed, socially desirable responding tends to be reduced in computer testing formats (Dwight \& Feigelson, 2000; Peck, Olsen, \& Devore, 2011) than in traditional ones, because respondents to online questionnaires may have the perception of being more anonymous (Lautenschlager \& Flaherty, 1990). For this reason, further social desirability measures should be developed and validated with better appropriate psychometric properties also for online investigation. This 
could improve research on well-being and quality of life because valid and reliable web surveys could offer a quick, simple, and costeffective solution to collect good quality data from large samples.

\section{References}

Andrews, D., Nonnecke, B., \& Preece, J. (2003). Electronic survey methodology: A case study in reaching hard to involve Internet Users. International Journal of Human-Computer Interaction, 16(2), 185-210. http://dx.doi.org/10.1207/ S15327590IJHC1602_04

Bäckström, M., Björklund, F., Larsson, M. R. (2009). Five-factor inventories have a major general factor related to social desirability which can be reduced by framing items neutrally. Journal of Research in Personality, 43, 335-344.

Ben-Zur, H. (2012). Loneliness, optimism, and well-being among married, divorced and widowed individuals. The Journal of Psychology, 146, 23-36. http:// dx.doi.org/10.1080/00223980.2010.548414

Bono, G., Emmons, R. A., \& McCullough, M. E. (2004) . Gratitude in practice and the practice of gratitude. In P. A. Linley and S. Joseph (Eds.), Positive psychology in practice (pp. 464-481). New York: Wiley.

Brajša-Žganec, A., \& Kaliterna Lipovčan, L. (2006). Kvaliteta življenja, životno zadovoljstvo i sreća osoba koje profesionalno pomažu drugima [Quality of life, life satisfaction and happiness in professional caregivers]. Društvena istraživanja, 4-5(84-85), 713-728.

Brajsa-Zganec, A., Ivanovic, D., \& Lipovcan, L. K. (2011). Personality Traits and Social Desirability as Predictors of Subjective Well-being. Psychological Topics, 20(2), 261-276. Retrieved from http://pt.ffri.hr/in dex.php/pt/article/view/2/2

Burris, C. T., \& Jackson, L. M. (1999). Hate the sin/love the sinner, or love the hater? Intrinsic religion and responses to partner abuse. Journal for the Scientific Study of Religion, 38, 160-174.

Caputo, A. (2015). The Relationship Between Gratitude and Loneliness: The Potential Benefits of Gratitude for Promoting Social Bonds. Europe's Journal of Psychology, 11(2), 323-334. https://doi.org/10.5964/ ejop.v11i2.826

Chen, P. Y., Dai, T., Spector, P. E., \& Jex, S. M. (1997). Relation between negative affectivity and positive affectivity: effects of judged desirability of scale items and respondents' social desirability. Journal of Personality Assessment, 69(1), 183-198. http://dx.doi.org/10.1207/ s15327752jpa6901_10

Costa, P. T., \& McCrae, R. R. (1984). Personality as a life-long determinant of wellbeing. In C. Z. Malatesta \& C. E. Izard (Eds.), Emotion in adult development (pp. 141-157). Beverly Hills, CA: Sage.

Crowne, D. P., \& Marlowe, D. (1960). A new Scale of social desirability independent of psychopathology. Journal of Consulting Psychology, 24, 349-354. http:// dx.doi.org/10.1037/h0047358

DeNeve, K. M., \& Cooper, H. (1998). The happy personality: A metaanalysis of 137 personality traits and subjective well-being. Psychological Bulletin, 124(2), 197-229. http:// dx.doi.org/10.1037/0033-2909.124.2.197

DeYoung, C. G., Peterson, J. B., Higgins, D. M. (2002). Higher-order factors of the Big Five predict conformity: Are these neurons of health? Personality and Individual Differences, 33, 533-552. http://dx.doi.org/10.1016/ S0191-8869(01)00171-4

Diener, E. (1984). Subjective well-being. Psychological Bulletin, 95, 542-575. http:// dx.doi.org/10.1037/0033-2909.95.3.542

Diener, E. (2000). Subjective well-being: The science of happiness and a proposal for a national indeks. American Psychologist, 55(1), 34-43. http:// dx.doi.org/10.1037/0003-066X.55.1.34 
Diener, E. (2009). Assessing Well-Being: The. Collected Works of Ed Diener. Dordrecht: Springer.

Diener, E., \& Biswas-Diener, R. (2002). Will money increase subjective wellbeing? Social Indicators Research, 57, 119-169. http://dx.doi.org/10.1023/ A:1014411319119

Diener, E., Emmons, R. A., Larsen, R. J., \& Griffin, S. (1985). The satisfaction with life scale. Journal of Personality Assessment, 49, 71-75. http:// dx.doi.org/10.1207/s15327752jpa4901_13

Diener, E., Sandvik, E., Pavot, W., \& Gallagher, D. (1991). Response artefacts in the measurement of subjective well-being. Social Indicators Research, 24, 35-56. http:// dx.doi.org/10.1007/BF00292649

Diener, E., Suh, E. M., \& Oishi, S. (1997). Recent findings on subjective well-being. Indian Journal of Clinical Psychology, 24(1), 25-41.

Duncan, E., \& Grazzani-Gavazzi, I. (2004). Positive Emotional Experiences in Scottish and Italian young Adults: A Diary Study. Journal of Happiness Studies, 5, 359-384. http://dx.doi.org/10.1007/ s10902-004-0666-8

Dwight, S. A., \& Feigelson, M. E. (2000). A quantitative review of the effect of computerized testing on the measurement of social desirability. Educational and Psychological Measurement, 60, 340-360. http:// dx.doi.org/10.1177/00131640021970583

Emmons, R. A., \& Crumpler, C. A. (2000) . Gratitude as a human strength: Appraising the evidence. Journal of Social and Clinical Psychology, 19, 56-67. http:// dx.doi.org/10.1521/jscp.2000.19.1.56

Evans, J. \& Mathur, A., (2005). The Value of On-line Surveys. Internet Research, 15(2), 195-219. http://dx.doi.org/ 10.1108/10662240510590360

Eysenck, M. (1990). Happiness: Facts and myths. Hillsdale, NJ: Lawrence Erlbaum Associates.
Fastame, C., \& Penna, M. P. (2013). Does Social Desirability Confound the Assessment of Self Reported Measures of Well-Being and Metacognitive Efficiency in Young and Older Adults? Clinical Gerontologist, 36(2), 95-112. http:// dx.doi.org/10.1080/07317115.2012.749319

Forgeard, M. J. C., Jayawickreme, E., Kern, M., \& Seligman, M. E. P. (2011). Doing the right thing: Measuring wellbeing for public policy. International Journal of Wellbeing, 1(1), 79-106. http://dx.doi.org/10.5502/ ijw.v1i1.15

Gallagher, E. N., \& Vella-Brodrick, D. A. (2008). Social support and emotional intelligence as predictors of subjective well-being. Personality and Individual Differences, 44(7), 1551-1561. http:// dx.doi.org/10.1016/j.paid.2008.01.011

Gosling, S. D., Vazire, S., Srivastava, S., \& John, O. P. (2004). Should we trust Web-based studies? A comparative analysis of six preconceptions about Internet questionnaires. American Psychologist, 59, 93-104. http:// dx.doi.org/10.1037/0003-066X.59.2.93

Holden, R. R., Starzyk, K. B., Mcleod, L. D., \& Edwards, M. J. (2000). Comparisons among the Holden Psychological Screening Inventory (HPSI), the Brief Symptom Inventory (BSI), and the Balanced Inventory of Desirable Responding (BIDR). Assessment, 7, 163-175.

Holder, M. D. (2012). Happiness in children: measurement, correlates and enhancement of positive subjective well-being. Dordrecht: Springer.

Holtgraves, T. (2004). Social desirability and self-reports: Testing models of socially desirable responding. Personality and Social Psychology Bulletin, 30, 161-172. http:// dx.doi.org/10.1177/0146167203259930

Howell, R. T., Rodzon, K. S., Kurai, M., \& Sanchez, A. H. (2010). A validation of well-being and happiness surveys for administration via the Internet. Behavior Research Methods, 42(3), 775-784. http:// dx.doi.org/10.3758/BRM.42.3.775 
Hughes, M. E., Waite, L. J., Hawkley, L. C., \& Cacioppo, J. T. (2004). A short scale for measuring loneliness in large surveys: Results from two population-based studies. Research on Aging, 26, 655-672. http:// dx.doi.org/10.1177/0164027504268574

Inglehart, R. (2002). Gender, aging, and subjective well-being. International Journal of Comparative Sociology, 43(3-5), 391-408. http:// dx.doi.org/10.1177/002071520204300309

Inglehart, R., \& Klingemann, H. D. (2000). Genes, culture, democracy and happiness. In E. Diener, \& E. M. Suh (Eds.), Culture and subjective well-being (pp. 165-183). Cambridge, Massachusets: The MIT Press.

Kaliterna-Lipovčan, L., \& Prizmić-Larsen, Z. (2006). Quality of life, life satisfaction and happiness in Croatia in comparison to European countries. In K. Ott (Ed.), Croatian accession to the European Union. The challenges of participation (pp. 189-208). Zagreb: Institute of Public Finances, Friedrich Ebert Stiftung.

Karademas, E. (2007). Positive and negative aspects of well-being: Common and specific predictors. Personality and Individual Differences, 43, 277-287.

Konow, J., \& Earley, J. (2008). The Hedonistic Paradox: Is Homo Economicus Happier? Journal of Public Economics, 92, 1-33. http:// dx.doi.org/10.1016/j.jpubeco.2007.04.006

Konstabel, K., Aavik, T., \& Allik, J. (2006). Social desirability and consensual validity of personality traits. European Journal of Personality, 20, 549-566. http:// dx.doi.org/10.1002/per.593

Kozma, A., \& Stones, M. J. (1988). Social desirability in measures of subjective wellbeing: Age comparisons. Social Indicators Research, 20, 1-14. http:// dx.doi.org/10.1007/BF00384215

Kuncel, N. R., \& Tellegen, A. (2009). A conceptual and empirical reexamination of the measurement of the social desirability of items: Implications for detecting desirable response style and scale development. Personnel Psychology,
62, 201-228. http://dx.doi.org/10.1111/ j.1744-6570.2009.01136.x

Lasgaard, M., Goossens, L., \& Elklit, A. (2011). Loneliness, depressive symptomatology, and suicide ideation in adolescence: Cross-sectional and longitudinal analyses. Journal of Abnormal Child Psychology, 39, 137-150. http://dx.doi.org/10.1007/ s10802-010-9442-x

Lautenschlager, G. J., \& Flaherty, V. L. (1990). Computer administration of questions: more desirable or more social desirability? Journal of Applied Psychology, 75, 310-314. http:// dx.doi.org/10.1037/0021-9010.75.3.310

Li, A., \& Bagger, J. (2006). Using the BIDR to distinguish the effects of impression management and selfdeception on the criterion validity of personality measures: A meta-analysis. International Journal of Selection and Assessment, 14, 131-140. http://dx.doi.org/10.1111/ j.1468-2389.2006.00339.x

Lucas, R. E., Clark, A. E., Georgellis, Y., \& Diener, E. (2004). Unemployment alters the set point for life satisfaction. Psychological Science, 15, 8-13. http://dx.doi.org/ 10.1111/ j.0963-7214.2004.01501002.x

Lyubomirsky, S., \& Lepper, H. S. (1999). A measure of subjective happiness: Preliminary reliability and construct validation. Social Indicators Research, 46, 137-155. http://dx.doi.org/10.1023/ A: 1006824100041

Lyubomirsky, S., Sheldon, K. M., \& Schkade, D. (2005) . Pursuing happiness: The architecture of sustainable change. Review of General Psychology, 9, 111-131. http:// dx.doi.org/10.1037/1089-2680.9.2.111

Maino, E., \& Aceti, G. (1997). Contributo all'adattamento italiano della MarloweCrowne Social Desirability Scale [Contribution to the Italian adaptation of the Marlowe-Crowne Social Desirability Scale]. Testing, Psychometrics, Methodology in Applied Psychology, 4(2), 81-93. 
Manganelli Rattazzi, A. M., Canova, L., \& Marcorin, R. (2000). La desiderabilità sociale: Un'analisi di forme brevi della scala di Marlowe e Crowne [Social desirability: An analysis of short forms of the Marlowe-Crowne Social Desirability Scale]. Testing, Psychometrics, Methodology in Applied Psychology, 7(1), 5-17.

McCrae, R. R. (1986). Well being scales do not measure social desirability. Journal of Gerontology, 41, 390-392. http:// dx.doi.org/10.1093/geronj/41.3.390

McCrae, R. R. (2002). The maturation of personality psychology: Adult personality development and psychological wellbeing. Journal of Research in Personality, 36, 307-317. http://dx.doi.org/10.1016/ S0092-6566(02)00011-9

McCrae, R. R., \& Costa, P. T. (1983). Social desirability scales: More substance than style. Journal of Consulting and Clinical Psychology, 51, 882-888. http:// dx.doi.org/10.1037/0022-006X.51.6.882

McCullough, M.E., Emmons, R.A., \& Tsang, J. (2002). The grateful disposition: A conceptual and empirical topography. Journal of Personality and Social Psychology, 82, 112-127. http:// dx.doi.org/10.1037/0022-3514.82.1.112

Myers, D. G. (2000). The funds, friends, and faith of happy people. American Psychologist, 55, 56-67. http://dx.doi.org/ 10.1037/0003-066X.55.1.56

Nederhof, A. J. (1985). Methods of coping with social desirability bias: A review. European Journal of Social Psychology, 15, 263-280. http://dx.doi.org/10.1002/ejsp.2420150303

Paulhus, D. L. (1991). Measurement and control of response bias. In J. P. Robinson \& P. R. Shaver (Eds.), Measures of personality and social psychological attitudes (pp. 17-59). San Diego: Academic Press.

Paulhus, D. L. (2002). Socially desirable responding: The evolution of a construct. In H. Braun, D. N. Jackson, \& D. E. Wiley (Eds.), The role of constructs in psychological and educational measurement (pp. 67-88). Hillsdale, NJ: Erlbaum.
Pavot, W., \& Diener, E. (2004). The subjective evaluation of well-being in adulthood: Findings and implications. Aging International, 29(2), 113-135. http:// dx.doi.org/10.1007/s12126-004-1013-4

Pavot, W., Diener, E., Colvin, C. R., \& Sandrik, E. (1991). Further validation of the Satisfaction with life scale: Evidence for the cross-method convergence of well-being measures. Journal of Personality Assessment, 51(19), 149-161. http:// dx.doi.org/10.1207/s15327752jpa5701_17

Peck, R., Olsen, C., \& Devore, J. (2011). Introduction to Statistics and Data Analysis (4th edition). Boston, MA: Brooks/Cole.

Penezić, Z., \& Ivanov, L. (1999). Predikcija zadovoljstva životom kod tri različite dobne skupine [Prediction of life satisfaction in three different age groups]. Psychological Topics, 8-9, 47-61.

Piccinelli, M., \& Wilkinson, G. (2000). Gender differences in depression: Critical review. British Journal of Psychiatry, 177, 486-492. http://dx.doi.org/ 10.1192/bjp.177.6.486

Powling, M., \& Hopes, W. (1988). Loneliness, self-characterization and acquaintance in student groups. Australian Psychologist, 23(1), 45-53. http:// dx.doi.org/10.1080/00050068808255595

Presser, S., \& Stinson, L. (1998). Data collection mode and social desirability bias in selfreported religious attendance. American Sociological Review, 6(3),137-145.

Randall, D., \& Fernandes, M. E. (1991). The social desirability response bias in ethics research. Journal of Business Ethics, 10, 805-817.

Richman, W. L., Weisband, S., Kiesler, S., \& Drasgow, F. (1999). A meta-analytic study of social desirability distortion in computeradministered questionnaires, traditional questionnaires and interviews. Journal of Applied Psychology, 84, 754-775. http:// dx.doi.org/10.1037/0021-9010.84.5.754

Russell, D., Peplau, L. A., \& Cutrona, C. E. (1980). The revised UCLA Loneliness Scale: Concurrent and discriminant validity evidence. Journal of Personality 
and Social Psychology, 39, 472-480. http:// dx.doi.org/10.1037/0022-3514.39.3.472

Ryan, R. M., \& Deci, E. L. (2001). On happiness and human potentials: A review of research on hedonic and eudaimonic well-being. Annual Review of Psychology, 52, 141-166. http://dx.doi.org/10.1146/ annurev.psych.52.1.141

Sigmon, S. T., Pells, J. J., Boulard, N. E., Whitcomb-Smith, S., Edenfield, T. M., Hermann, B. A., ... Kubik, E. (2005). Gender differences in self-reports of depression: The response bias hypothesis revisited. Sex Roles, 53, 401-411. http:// dx.doi.org/ 10.1007/s11199-005-6762-3

Smith D. B., \& Ellingson, J. E. (2002). Substance versus style: A new look at social desirability in motivating contexts. Journal of Applied Psychology, 87(2), 211-219. http:// dx.doi.org/10.1037/0021-9010.87.2.211

Solano, L., \& Coda, R. (1994). Relazioni, emozioni, salute: Introduzione alla psicoimmunologia [Relationships, emotions and health: Introduction to psychoimmunology]. Padova: Piccin.

Soubelet, A., \& Salthouse, T. A. (2011). Influence of social desirability on age differences in self reports of mood and personality. Journal of Personality, 79(4), 741-762. http://dx.doi.org/10.1111/ j.1467-6494.2011.00700.x

Steel, P., \& Ones, D. S. (2002). Personality and happiness: A nationallevel analysis. Journal of Personality and Social Psychology, 83, 767-781. http:// dx.doi.org/10.1037/0022-3514.83.3.767

Tan, L., \& Grace, R. C. (2008). Social desirability and sexual offenders: A review. Sexual Abuse: A Journal of Research and Treatment, 20(1), 61-87.

Veenhoven, R. (1991). Questions on Happiness: Classical Topics, Modem Answers, Blind Spots. In E. Strack, M. Argyle, \& N. Schwarz (Eds.), Subjective Well-Being: An Interdisciplinary Perspective (pp. 7-26). Oxford: Pergamon.
Vereecken, C. A., \& Maes, L. (2006). Comparison of a computeradministered and paper-andpencil-administered questionnaire on health and lifestyle behaviors. Journal of Adolescent Health, 38(4), 426-432. http://dx.doi.org/10.1016/ j.jadohealth.2004.10.010

Watkins, P. C. (2004). Gratitude and subjective well-being. In R. A. Emmons \& $\mathrm{M}$. E. McCullough (Eds.), The psychology of gratitude (pp. 167-194). New York: Oxford University Press. http://dx.doi.org/10.1093/ acprof:oso/9780195150100.003.0009

Watson, D., Pichler, F., \& Wallace, C. (2010). Second European Quality of Life Survey: Subjective Well-being in Europe. Luxembourg: Office for Official Publications of the European Communities. Wood, A. M., Froh, J. J., \& Geraghty, A. W. A. (2010). Gratitude and well-being: A review and theoretical integration. Clinical Psychology Review, 30, 890-905. http:// dx.doi.org/10.1016/j.cpr.2010.1003.1005

Wood, A. M., Joseph, S., \& Linley, P. A. (2007). Gratitude: The parent of all virtues. The Psychologist, 20, 18-21.

\section{Notes}

* Research article

i The sample items mentioned are derived from the Edwards Social Desirability Scale (1957). 